\title{
AN EVALUATION OF ENGLISH LEARNING MATERIALS FOR INFORMATION AND TECHNOLOGY STUDENTS DEPARTMENT AT POLITEKNIK NEGERI PADANG
}

\author{
*Indri Astuti \\ English Education Program, Universitas Negeri Padang, Indonesia \\ Email: indre.ngoocol@gmail.com
}

*Corresponding Author, Received: November 12, 2018, Revised: December 10, 2018, Accepted: December 21, 2018

\begin{abstract}
This study aimed to get the criteria for English language teaching materials needed by Padang State Polytechnic Information and Technology students and evaluate English teaching materials that were used to determine the level of compatibility of teaching materials used with criteria obtained in terms of language, content, and methodology. This research was an evaluation research. Questionnaires, interviews, and analysis formats were used to obtain data. The results of data analysis showed that: (1) criteria for English language teaching materials were needed by students majoring in Information and Technology in terms of language indicated that the teaching material used was in accordance with the needs of students, majors, and their level of English; in terms of the content of teaching material used had an emphasis on speaking and listening skills and teaching materials used for writing and reading were still lack; in terms of the methodology of teaching materials used were equipped with activities that train speaking skills so that training and assignments were focused on practicing speaking skills. (2) The level of compatibility of teaching material in terms of language was $58 \%$. (3) The level of compatibility of teaching material in terms of contents, namely $42 \%$. (4) The level of compatibility of teaching materials used in terms of methodology was $42 \%$. Based on the results of the study, it could be concluded that students majoring in Information and Technology needed material that could improve their listening and speaking skills, then the material used in writing and reading was further reproduced.
\end{abstract}

Keywords: Evaluation, Material Evaluation, English for Specific Purposes (ESP), Information and Technology Students

\section{INTRODUCTION}

English language has become international languages. Because of the uses of English language itself, every Indonesians students need to learn English. There are two 


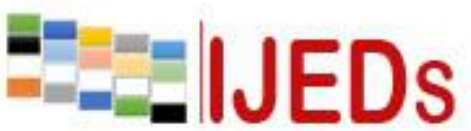

http://ijeds.ppj.unp.ac.id/index.php/IJEDS

types of learning English at education, general English and English for specific purposes. English for general purposes is designed to teach English language generally. For example English in senior high School or junior high school. In senior high school or junior high school, the teacher teaches English generally, such as reading, writing, listening and speaking. Different from general English, English for specific purposes is learning English more specific. According to Robinson in Dudley Evans (2008) ESP course are generally constrained by limited time period, in which their objective have to be achieved and are taught to adults in homogeneous classes in term of the work or specialist studies that students are involved in.

ESP is divided into two main areas, English for academic purposes and English for occupational purposes. English for academic purposes is divided into several brances, they are English for science and technology, English for medical purposes, English for legal purposes, and English for management, finance and economics. Then English for occupational purposes is divided into English for professional purposes and English for vocational purposes.

PolitehnikNegeri Padang is one of several universities that apply English for specific purposes in their class. ESP is taught in first and second grade students and English for TOEFL is taught in last grade student. The purpose of learning ESP is to increase students knowledge in order to achieve the target in English language, for example the information and technology student in Politehnik Negeri Padang. The information and technology students learn English 2 hours a week.

In preliminary research which has been conducted, the researcher found that the materials that they use were conducted in 2007. It means that the material was never being evaluated for a long time. Thus the lecturer made the materials without considering students need. It means that they made the materials only through their perspective without did the need analysis. For those reasons the researcher suggest there is need an evaluation of the materials because the materials had been evaluated for long time then the need analysis also important in learning English for ESP. As Hutchinson and waters state "what distinguishes ESP from general English is not the existence of a need as such but rather an awareness of the need". 


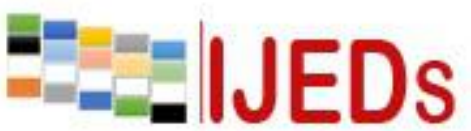

http://ijeds.ppj.unp.ac.id/index.php/IJEDS

Material is crucial part in learning ESP. according to Dudley Evans there are four reasons that material is important in learning ESP, first materials is used as a source of language, second material is used as a learning support, third material is used for motivation and stimulation and last material is used for reference (1998). Related to that reason, material that is used in information and technology students are important in order to achieve the target. The materials should be relevant to student, such as suitable to carrier content, matching real content to learning and real world activities, composing the clear rubric, and planning an effective layout. Then it is important to do the need analysis in making the material for students who learn ESP, as Hutchinson and Waters stated that material design in learning ESP is started with " why do these learners need to learn English?” question (1998). Unfortunately the material that given to information and technology students are made without considering the students need. Then the material was designed only from teacher perspective who is not expert in Information and Technology area. After that, the material never been revised since the beginning.

Based on the explanation above, the material evaluation of Information and technology student is needed. It is important because related to the student achievement for the work field. Tomlinson states that the course book evaluation is procedure that measures the value of a set material. It is included making judgementabout the effect of coursebook on teacher and students that use them (2013). Thus the research will be conduct to valuate English material for information and technology students in PolitehnikNegeri Padang. The material will be evaluated according to language area, content and methodology. Then the researcher will do need analysis based on students need and paired it with teachers point of view in order to make better material.

To strengthen the analysis of this research, some researchers were used as the basic consideration of material evaluation. First Irwandi (2007), a post graduate students of state university of padang. He evaluate English text book for junior high school student in padang. The result of his research shows some books are lack of material presentation and communicative aspect, and other books already have good qualification in presentation and communicative aspect. Second, a research from Dakhmouche Farida Ross which entitled “Meeting Students Need: An Analysis of ESP 


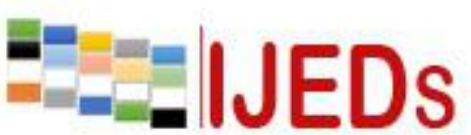

http://ijeds.ppj.unp.ac.id/index.php/IJEDS

Teachnig at the Department of Computer Science.” In his research he analyze the need analysis of five years student at computer science department and compare with the effectiveness of the learning process in ESP. The result of his research shows that students were more effective learn English in ESP rather than not with ESP. Third, a research from El Sakran(2012) which entitled “ evaluation of English for specific purposes (ESP) book for students of Islamic and Arabic Studies". In his research he analyze the book that is used in learning process. The result of his research shows that the ESP book is lead the students to near native speaker competence.

In addition, Rahmini (2011) evaluated the textbook English for students of sociology. Social science text taught at the University of Teheran, Iran. The purpose of this research was to determine the overall pedagogical value and suitability of the book toward the specific language program. The finding is the book was not very suitable for the course. In conclusion there are several research that have similarity to this research. They are conduct research about material evaluation and ESP. however this research is also conduct about material evaluation in ESP. the researcher will evaluate the material of Information and Technology students in PolitehnikNegeri Padang. Then the research will be focus on language area, content and methodology.

\section{METHOD}

This research was conducted by using evaluation research. According to Gay and Airasian (2003), the focus of evaluation research is making decision and judgment about the quality, effectiveness, merit, or value of educational program, product or practice. In this research, the evaluation research was conducted on English material of Information and Technology students in Politehnik Negeri Padang. The materials was evaluated by using the theories from Hutchinson and Waters (2008) and Tomlinson (2013). The result hopefully can be useful for the improvement of quality in teaching English for specific purposes in Politehnik Negeri Padang. 


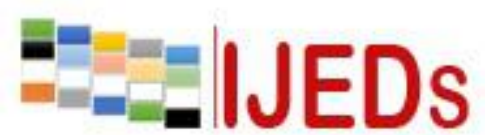

http://ijeds.ppj.unp.ac.id/index.php/IJEDS

\section{RESULTS AND DISCUSSION}

In this part, there were four things will be discussed; (1) what the criteria of English materials appropriately needed for Information and Technology students of Politehnik Negeri Padang are, (2) how the language area of material material used by Information and Technology students of PolitehnikNegeri Padang is, (3) how the content of material used by Information and Technology of Politehnik Negeri Padang is, and (4) how the methodology of material used by Information and Technology of Politehnik Negeri Padang.

\section{The Criteria of English Material Appropriately Needed for Information and Technology Department of PolitehnikNegeri Padang}

Need analysis was conducted to collect information about students need in order to obtain the criteria of English material appropriately needed for Information and Technology Department of PolitehnikNegeri Padang. The analysis focused on three criteria. They were language area, content and methodology.

The result of the need analysis show that the Information and Technology students were needed to learn English because of some reason. According to the interview from the lecturer, they need learn English in order to support their job after they graduated from PolitehnikNegeri Padang. Then the term in their lesson such as java or animation used English language. It can be conclude that the students need to learn English because they need to present their application that been made to the customer. As Bojovic (2006) state that the good materials for English Academic Purposes (EAP) program have to be purpose oriented. It means that the English material should be designed based on students need.

Then, the data finding shows that the Information and Technology students need to learn English that related to computer terminologies such as Java and coding. It means the material should be related to computer terminologies in order to obtain the students needs. According McDonough, Shaw and Masuhara (2013), in teaching English for Academic Purposes (EAP), subject- specific materials are needed because different field need different materials. It can be conclude that Information and 


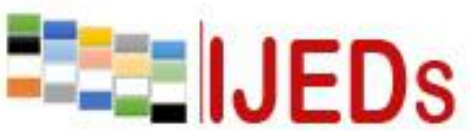

http://ijeds.ppj.unp.ac.id/index.php/IJEDS
International Journal of Educational Dynamics

Vol. 1 No. 1 (pp. 18-29) December 2018

p_ISSN 2655-4852

e ISSN 2655-5093

Technology students need to learn English in their terminologies, such as Java or coding.

Moreover, the data finding shows the Information and Techonolgy students had various level in English language. Most of them were in the medium level. It can be said that the materials for Information and Technology student must be suitable for their level. As Hyland (2006) stated that the difficulty of teaching material should be higher that the current level of the students. If the materials are beyond students proficiency, they may feel discourage and frustrated, however if the materials are too simple, it is difficult to get attention from students.

Based on data findings, all skill were important for Information and Technology students, however speaking skill was the most important skill for them. According to McDonough, Shaw and Masuhara (2013), in English for Academic Purposes (EAP), all language skills are treated, however the language skills needed by the students are more emphasized. It means that the materials should emphasized speaking skills for the students, because from need analysis the speaking skills was more needed than other skills.

Moreover, grammar and vocabulary were next important skills needed for Information and Technology students. They needed to learn grammar to use related to the speaking skill and Information and Technology terminologies. Thus, they also need to increase their vocabulary to know Information and Technology terminologies so they can present their ideas. It can be conclude that grammars and vocabulary should be introduced in meaningful context in material. It is supported by Hutchinson and Waters (1987) grammars and vocabularies should be presented clearly, contextual and reinforced with extensive practice.

Then from the data it can be seen Information and Technology students needed more opportunities to practice their speaking ability. It means that the material should be organized based on communication task. It is supported by McDonough, Shaw and Matsuhara (2013) who state that the materials is to improve students speaking ability, therefore the materials should be organized based on communication task.

Based on the students need analysis, the Information and Technology students they need to learn English in communication such as present their work and understand 


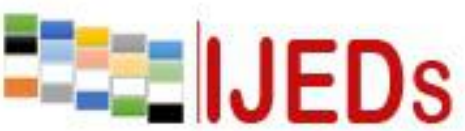

http://ijeds.ppj.unp.ac.id/index.php/IJEDS
International Journal of Educational Dynamics

Vol. 1 No. 1 (pp. 18-29) December 2018

p_ISSN 2655-4852

e_ISSN 2655-5093

the terminologies of Information and Technology such as Java, coding, and animation. Therefore the materials should be related to those activities. According to McDonough, Shaw and Masuhara (2013), the exercises and task given in the materials should be suitable for provided activities. It means that the task and exercises given to Information and Technology students should related to the activities that they were needed.

Then, the students should be active during teaching and learning process in order to practice their speaking skill. It can be said that the materials used should emphasized several activities which can improve their speaking skill. It is supported by Tomlinson (2013) who state that the activities provided in the materials should be students oriented which guide them to actively involve in learning. It can be conclude that the materials for Information and Technology students should support their speaking skill, such as group discuss, presentation or role play.

\section{Language Area of English Materials Used by Information and Technology Student of Politehnik Negeri Padang}

Language area evaluation of English materials used by Information and Technology students could be seen from the indicator of audience and aims. The first indicator was audience. They were three sub indicators related to audience; students level, English proficiency and specialism. The materials used in the classroom should be suitable for students level, whether they were junior, senior or university students. As Hutchinson and Waters (1987) say that the good materials have to be suitable for the level of intended audience, because the topic that will motivate one audience will probably not be suitable for another. Based on data findings, all skill were important for Information and Technology students, however speaking skill was the most important skill for them. According to McDonough, Shaw and Masuhara (2013), in English for Academic Purposes (EAP), all language skills are treated, however the language skills needed by the students are more emphasized. It means that the materials should emphasized speaking skills for the students, because from need analysis the speaking skills was more needed than other skills.

Moreover, grammar and vocabulary were next important skills needed for Information and Technology students. They needed to learn grammar to use related to 


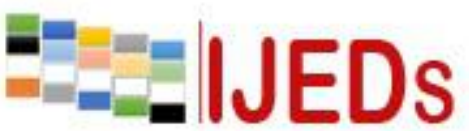

http://ijeds.ppj.unp.ac.id/index.php/IJEDS

the speaking skill and Information and Technology terminologies. Thus, they also need to increase their vocabulary to know Information and Technology terminologies so they can present their ideas. It can be conclude that grammars and vocabulary should be introduced in meaningful context in material. It is supported by Hutchinson and Waters (1987) grammars and vocabularies should be presented clearly, contextual and reinforced with extensive practice.

Then from the data it can be seen Information and Technology students needed more opportunities to practice their speaking ability. It means that the material should be organized based on communication task. It is supported by McDonough, Shaw and Matsuhara (2013) who state that the materials is to improve students speaking ability, therefore the materials should be organized based on communication task.

\section{Content of English Materials Used by Information and Technology Student of Politehnik Negeri Padang}

The next criterion of the evaluation of students materials used by Information and Technology students was the content of the materials. They are tree indicator that related to the content. The first one was the language points. The second one was the micro skill. Then the last one was text type. There were four indicator related to the language points. They were on sub indicator for grammar and three sub indicator for vocabulary. Based on the data finding, the materials used by Information and Technology students were suitable for grammar criteria. In the materials there were exercises about grammar but without further explanation. Then, the materials only suitable for two sub indicator related to the vocabulary. It means that the materials were less suitable for the vocabulary criteria. Hutchinson and Waters (1987) say that vocabularies should be presented based on students level and need. It can be conclude that the materials used by Information and Technology students of PolitehnikNegeri Padang need some revision and improvement related to the vocabulary.

Next second indicator of content criterion was micro skills. The materials should be designed based on language skills needed. Based on need analysis result, speaking was the most skills needed by Information and Techno logy students. The stakeholder say that their future job position require then to be able to master English. 


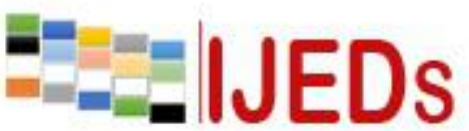

http://ijeds.ppj.unp.ac.id/index.php/IJEDS

In fact, the materials used by Information and Technology students of PolitehnikNegeri Padang were less suitable for the micro skill. According to McDonough, Shaw and Matsuhara (2013), in English for Academic Purposes (EAP) program, all language skill are treated, however the language skills needed by the students are more emphasized. For that reason the materials need some revision and improvement in micro skill indicator.

The last indicator of content criterion was the text type. Based on the data, the materials used by Information and technology students of PolitehnikNegeri Padang were less suitable for the text type criterion. According McDonough, Shaw and Masuhara (2013), subject specific materials are needed in teaching English for Academic Purposes. It means the topics presented should related to the students field. It can be conclude that the materials used by Information and Technology of Politehnik Negeri Padang need some revision and improvement especially related to the text type.

Finally based on the interpretation of the mean score of content criterion, it can be concluded that only some materials used by Information and Technology students of PolitehnikNegeri Padang matched to the indicator of language points, micro skill and text type. Thus the material used by Information and Technology students of Politehnik Negeri Padang need some revision related to the indicator of language points, micro skill and text type.

\section{Methodology of English Material Used by Information and Technology Students of Poltehnik Negeri Padang}

The evaluation of the materials used by Information and Technology of Politehnik Negeri Padang in methodology criterion consists of some indicator. They are kinds of exercises, teaching and learning techniques, guide/ support and flexibility of the materials. The evaluation of the materials used by Information and Technology of Politehnik Negeri Padang in methodology criterion consists of some indicator. They are kinds of exercises, teaching and learning techniques, guide/ support and flexibility of the materials. The first indicator was kinds of exercises and task. Based on the data, the exercises and task were suitable for assessing students comprehension but less suitable for students production. McDonough, Shaw and Masuhara (2013) state that the 


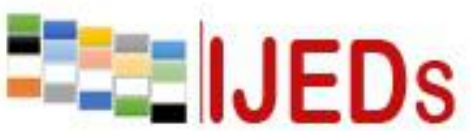

http://ijeds.ppj.unp.ac.id/index.php/IJEDS
International Journal of Educational Dynamics

Vol. 1 No. 1 (pp. 18-29) December 2018

p_ISSN 2655-4852

e ISSN 2655-5093

exercises and tasks given in the materials should be suitable for the activities provided. It can be conclude that the materials used by Information and Technology students of Politehnik Negeri Padang need some revision and improvements especially relate to indicator kinds of exercises and task.

The second indicator was teaching and learning technique. The materials should provide several teaching learning techniques. According to Hutchinson and Waters (1987), the teaching learning technique can be taugh by pair work, small group work, students presentation and other kinds activities. Those several techniques can be applied to achieve the objective of teaching and learning process. From the data it can be seen that the materials used by Information and Technology students of Politehnik Negeri Padang were suitable for the criterion.

The next indicator was guide or support. McDonough, Shaw and Masuhara (2013) state that the good materials should have a clear guide for lecturer and students to do the various activities. From the data it can be seen that the materials were less suitable for Information and Technology students in guide or support criterion. For that reason the materials used by Information and Technology students of Politehnik Negeri Padang need some revision and improvements especially related to the indicator guide or support.

The last indicator was flexibility. According to Tomlinson (2013), good materials should be flexible. They can be linked to other materials that are taken from other references and can be used by teaching aids. Based on the data findings, it can be said that in general the materials used by Information and Technology students of Politehnik Negeri Padang was suitable for indicator of flexibility. Finally, based on the interpretation of the mean score of the methodology criterion, it can be summed up that some materials of the Information and Technology students of PolitehnikNegeri Padang matched to the indicator teaching learning techniques and flexibility, while only some materials matched to the indicators of kinds of exercises and guide or support. In conclusion, the materials used by Information and Technology students of Politehnik Negeri Padang need some revision and improvements especially in indicator kinds of exercises and guide or support. 


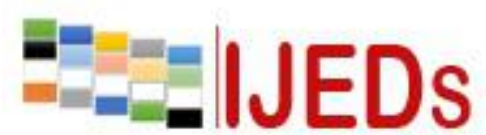

http://ijeds.ppj.unp.ac.id/index.php/IJEDS

\section{CONCLUSION}

Materials that needed by Information and Technology students should be suitable for students. Then the materials should be related to Information and Technology terminologies. The difficulty of materials should be suitable for Information and Technology students which is medium level. Speaking is the most skill that needed by Information and Technology students. However the other skills such as vocabulary, grammar, listening and other skill are needed too. The topic presented should be related to Information and Technology terminology. Then the materials should be interesting, authentic and focus to the students. The exercises and the tasks should not only asses the students comprehension. However they should be more focused to asses students production. Many of English materials used by Information and technology students of Politehnik Negeri Padang match to the indicator of audience. Then there also many of English materials used by Information and Technology Students match to the indicator of aims. Many of English materials used by Information and Technology students matched to the indicator of vocabulary. Meanwhile there were only some materials used by Information and Technology matched the indicator of micro skills and text type. Many of English materials used by Information and Technology students match to indicator flexibility. Meanwhile only some materials used by Information and Technology students matched indicator teaching learning technique, kind of exercises and task and guide or support.

\section{REFERENCES}

Bojović, Milevica. 2006. Teaching Foreign Language for Specific Purposes: Teacher Development. http://www.pef.uni-1j.si/atee/978-961-6637-06-0/487-493.pdf.

Gay, L. R and P. Airasian. 2003. Educational Research: Competencies for Analysis and Application $\left(7^{\text {th }}\right.$ ed $)$. New Jersey: Pearson Education, Inc.

Hutchinson, T. and A. Waters. 2008. English for Specific Purposes: A Learning-centred Approach ( $23^{\text {rd }}$ printing). Cambridge: Cambridge University Press.

Irwandi. 2007. An Analysis of English Textbooks for Junior High School. Unpublished thesis. Padang: English Section. Graduate Program.

Kontozi, Andrie. 2011. Analysis and Evaluation of English $6^{\text {th }}$ Grade textbook Used in Greek Public School.Retrived on September 15 ${ }^{\text {th }}, 2014$. 
http://ijeds.ppj.unp.ac.id/index.php/IJEDS

MomtazurRahman, Md. 2012. The English Language Needs of Computer Scince Undergraduate Student At Putra University Malaysia. Putra University Malaysia. http://www.esp-world.info/Articles_34/DOC/ESP_Rahman.pdf

McDomough, J., Shaw, C., Matshuhara, H,.Materials and Method in ELT: A Teacher's Guide. Oxford: Blackwell.

Tomlinson, B. (ed). 2013. Developing Material for Language Teaching. London: Continuum 